\title{
French research budget wins increase, but few new posts
}

Paris. Research fared relatively well in France's austerity budget last week, with the government promising in particular to alleviate the funding crisis at the Centre National de la Recherche Scientifique (CNRS). But there is a virtual freeze on scientific recruitment.

Overall, the harsh cuts in public spending were not unexpected. France is struggling to reduce its spiralling budget deficit - which is estimated at more than FF322 billion (US\$64.4 billion) this year - in a bid to meet the criteria agreed under the Maastricht Treaty for participation in Europe's Economic and Monetary Union. The government is also under pressure to reduce both direct and indirect taxes, which at 44.7 per cent of gross national product are the highest of any industrialized country.

But Alain Juppé, the prime minister, refrained from making deep spending cuts, a decision that has been strongly criticized by the financial markets. The move was made partly to honour promises made by Jacques Chirac, the French president, during his election campaign earlier this year. Overall public spending is set to increase by 1.8 per cent next year, compared with a predicted level of inflation of 2.2 per cent.

Research emerges as one of the main winners in the budget, increasing by 2.4 per cent over the revised budget for 1995 - or 1.4 per cent compared with the previous government's request - to FF53.09 billion.

The increase is a personal success for Elisabeth Dufourcq, the new secretary of state for research. Many observers had questioned whether she would be able to defend research spending, often considered an easy target for the finance ministry in an austerity budget. "We can't say research has been badly treated", says Dufourcq.

Within the civil research and development budget (see figure below), the main research organizations receive large increases, confirming their role as the main forces

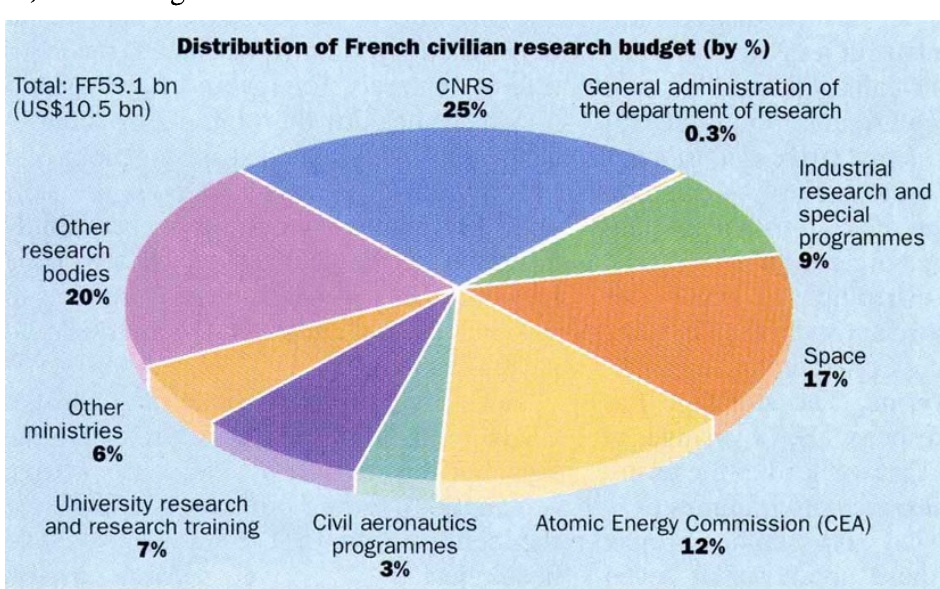

shaping French research. This confirms Dufourcq's confidence in the agencies, and her reluctance to increase the central role of her own ministry in shaping French research, a policy her predecessor, François Fillon, had seemed keen to promote.

The CNRS, for example, will have its funds increased by 3.66 per cent to FF13.1 billion, the national biomedical research agency, INSERM, by 5.27 per cent to FF2.25 billion, and the national agricultural research organization, INRA, by 5.97 per cent to FF3.3 billion.

Of the money allocated to CNRS, FF277 million is intended to alleviate the funding crisis at the agency. This time last year the agency told its researchers that they could spend no more than 60 per cent of the funds they had been allocated for the year (see Nature 371, 192; 1994), following the discovery of a gap in the agency's finances of more than FF1 billion.

This deficit had grown because cash payments from the government had failed to keep up with promises made in the budget. The new injection of funds follows an extra FF400 million provided earlier this year, and the agency now hopes to stabilize its financial situation in 1996.

Dufourcq also obtained an additional FF800 million for her ministry's own research funds, which had accumulated an even larger deficit than that of CNRS for the same reasons. The funds, which are used to support industrial and other special projects, had previously been "a target for the finance ministry”, said Dufourcq.

Referring to the financial crisis at CNRS and her own ministry, Dufourcq says she inherited a financial situation that was "not brilliant". She also promises that the 1996 budget was free of the artificial promises that has brought about these crises. "I have decided to lance the abscess", she says. But recruitment in the research sector
became one victim of the emphasis that Dufourcq placed on rectifying the financial situation.

As a result of the financial stringency, only eight new posts will be created next year for the whole of the scientific community.

"It wasn't the priority," said Dufourcq.

Declan Butler

\section{IMAGE UNAVAILABLE FOR COPYRIGHT REASONS}

Lapping it up: a Hindu statue 'feeds' on milk.

\section{India's 'milk miracle' is hard to swallow}

New Delhi. Science took a hammering from religion last week when millions of Hindus packed temples all over the world to offer milk to Ganesha, the elephant god. They had heard - by word of mouth, over the radio or by telephone - that the stone idols were drinking milk by the spoonful, a manifestation of the presence of God himself.

Many of those who lined up to spoonfeed the deities watched the milk disappear as soon as it came into contact with the wet surface of the idols' trunks. The unlucky ones whose spoons remained filled had to swallow the priestly admonition that their belief was not strong enough.

But the All India Scientists and Rationalists Association, based in Calcutta, dismissed the 'milk miracle' as a hoax. "What people saw was simply a demonstration of capillary and surface tension at work," explained Professor Yash Pal, the government's former science secretary.

Scientists at the National Council for Science and Technology Communication added a red dye to milk and showed the coloured milk being sucked in by capillary action dripping from an idol's body. Leading scientists in Madras signed a statement calling on educated Indians to ensure "that primitive obscurantism and superstition did not hold sway over a society on the threshold of the 21st century".

The Delhi Science Forum, an organization committed to improving scientific literacy, described the apparent miracle as a well-planned conspiracy designed to arouse communal emotions. The forum suggested that people with a knowledge of physics may have introduced spoon-feeding "to create the conditions for the miracle to occur".

Few know how the affair started. But the ruling Congress government blamed the opposition pro-Hindu Bharatiya Janata Party for spreading the rumour in order to use the religious feelings aroused to gain support in the forthcoming elections.

The Vishwa Hindu Parishad, self-styled Hindu guardians, claimed the 'miracle' signalled a Hindu revival. K. S. Jayaraman 